\title{
Differential Protooncogene Expression Characterizes Histopathologically Indistinguishable Tumors of the Peripheral Nervous System
}

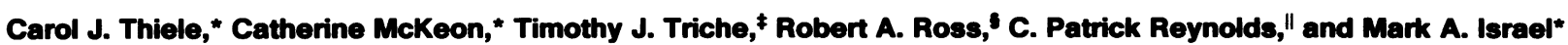
Molecular Genetics Section, *Pediatric and ${ }^{\ddagger}$ Pathology Branches, National Cancer Institute, National Institutes of Health, and Transplantation Research Program Center, "Naval Medical Research Institute, Bethesda, Maryland 20892;

Department of Biological Sciences, Fordham University, Bronx, New York 10458

\begin{abstract}
We have found highly predictable patterns of protooncogene expression in cell lines and tumor tissue of neuroblastoma (NB), a tumor of the peripheral nervous system (PNS). These patterns make it possible to recognize two different genetically definable subgroups among histopathologically indistinguishable tumors. Additionally, we have identified a difference in neurotransmitter biosynthetic enzyme activity in these two subgroups of NB. The patterns of protooncogene expression and neurotransmitter biosynthetic enzymes suggests that these tumors arise in different cells of the PNS.
\end{abstract}

\section{Introduction}

Neuroblastoma (NB) ${ }^{1}$ is a tumor of the peripheral nervous system that is thought to arise in primitive cells derived from the embryonal neural crest. $50 \%$ of advanced stage neuroblastoma tumor tissues have been found to have variable levels of amplification of the N-myc gene (1), and it has been suggested that amplification and expression of this gene is associated with rapid clinical progression of this highly malignant neoplasm (2). We have recognized a subgroup of NB tumors that are characterized by a specific chromosomal rearrangement, $\mathrm{t}(11 ; 22)(\mathrm{q} 24 ; \mathrm{q} 12)(3)$. Although these tumors are histologically indistinguishable from primitive NB characterized by the amplification of the $\mathrm{N}-m y c$ oncogene (NB-N), they do have a number of clinical features by which they can be recognized and therefore have been called neuroepithelioma (NE) (3).

Although NB-N occurs in early childhood and presents typically in the adrenal gland or at other sites of known sympathetic nervous system tissue, NE most frequently occurs in older children and young adults and seems to most frequently present on the chest wall or in an extremity (4). It is likely that most cases of adult neuroblastoma $(5,6)$ or peripheral neuroblastoma $(7,8)$, as well as the small round cell tumor of the chest wall, Askin's tumor (4), are all neuroepithelioma. These clinical differences complement the observation that, immu-

Address reprint requests to Dr. Thiele, Molecular Genetics Section, National Institutes of Health, Building 10, Room 13N240, Bethesda, MD 20892.

Received for publication 6 January 1987 and in revised form 13 April 1987.

1. Abbreviations used in this paper: CAT, cholineacetyl-transferase; DBH, dopamine-B-hydroxylase; MOPS, morpholine propanesulfonic acid; NB, neuroblastoma; NE, neuroepithelioma; SSC, standard saline citrate; TH, tyrosine hydroxylase.

The Journal of Clinical Investigation, Inc.

Volume 80, September 1987, 804-811 nocytochemically, NE, but not NB-N, expresses class I histocompatibility antigens (9).

To further characterize these two closely related tumors, we examined the relative levels and patterns of protooncogene expression in NE and NB-N. Protooncogenes are the normal cellular homologues of retroviral oncogenes (10). These genes are highly conserved throughout evolution and are likely to be important for normal cellular functions such as proliferation, growth, and differentiation (11-15). In general, studies examining protooncogene expression in specific human tumors report a highly variable pattern of expression, and the level of expression in different specimens of any particular tumor type is usually unpredictable (16-18). In sharp contrast to these studies, we have found in cell lines and tissue specimens of NB highly predictable patterns of protooncogene expression associated with the distinct biologic and genetic subgroups of this tumor, NB-N and NE. Furthermore, we have identified a difference in the neurotransmitter enzymes expressed in these tumors. These findings support the concept that NB-N and NE are distinct tumor entities and suggests that they may arise in different cells of the peripheral nervous system.

\section{Methods}

Cell lines. The following NB-N cell lines; SMS-KCN, SMS-KCNR, SMS-KAN, SMS-SAN (19), LA-N-5 (20), and IMR-32 (21), and NE cell lines; N1000, TC-32, N1008, N1016, N1043 (22), SK-N-MC (23), and CHP-100 (24) were utilized in this study.

Enzyme assays. NE and NB-N cell lines were plated into $150-\mathrm{mm}$ tissue culture dishes in RPMI 1640 supplemented with 15\% fetal calf serum, incubated at $37^{\circ} \mathrm{C}$ with $5 \% \mathrm{CO}_{2}$, and cells were harvested at confluence. The cells were mechanically detached from the dishes, frozen at $-70^{\circ} \mathrm{C}$ and assayed for neurotransmitter biosynthetic enzyme activity as previously described (25). The values represent the mean of triplicate assays on replicate cultures that were coded before assay. The activity of the neurotransmitter biosynthetic enzymes, tyrosine-hydroxylase (TH), dopamine-B-hydroxylase (DBH) and cholineacetyl-transferase (CAT) is expressed as the amount of product formed per hour per milligram of protein.

Isolation and analysis of nucleic acids. High molecular weight DNA was prepared as previously described (26). $15 \mu \mathrm{g}$ of genomic DNA was digested to completion with $5 \mathrm{U}$ of Eco R1 (Boehringer Mannheim Biochemical, Indianapolis, IN) per $\mu \mathrm{g}$ DNA, electrophoresed in a $0.7 \%$ agarose gel and transferred onto nitrocellulose essentially as described by Southern (27). Nitrocellulose blots were hybridized with ${ }^{32} \mathrm{P}$-labeled recombinant plasmid DNA containing cloned protooncogene segments for $24 \mathrm{~h}$ at $42^{\circ} \mathrm{C}$ in $50 \%$ formamide, $5 \times$ standard saline citrate $(1 \times \mathrm{SSC}=0.1 \mathrm{M} \mathrm{NaCl}, 0.015 \mathrm{M}$ sodium citrate, pH 7.0), $50 \mathrm{mM} \mathrm{Na} \mathrm{HPO}_{4}, 5 \times$ Denhardt's solution, $100 \mu \mathrm{g} / \mathrm{ml}$ sheared salmon sperm DNA (Sigma Chemical Co., St. Louis, MO), $10 \%$ Dextran sulphate, washed twice in $2 \times$ SSC, $0.1 \%$ SDS for 15 min at $25^{\circ} \mathrm{C}$ and twice in $0.2 \times$ SSC, $0.1 \%$ sodium dodecyl sulfate (SDS) for $30 \mathrm{~min}$ at $60^{\circ} \mathrm{C}$ and exposed to $\mathrm{X}-\mathrm{Omat} \mathrm{AR}$ film with a lightening plus intensifying screen at $-70^{\circ} \mathrm{C}$. Cytoplasmic or poly(A)+ RNA was iso- 
lated from tissue culture cell lines as previously described (28) while tumor RNA was isolated by the method of Chirgwin (29). RNA was denatured in $2.2 \mathrm{M}$ formaldehyde; $50 \%$ formamide; $0.2 \mathrm{M}$ morpholine propanesulfonic acid (MOPS), pH 7.0; $50 \mathrm{mM}$ sodium acetate; $1 \mathrm{mM}$ EDTA, pH 7.0; for $5 \mathrm{~min}$ at $65^{\circ} \mathrm{C}$. The samples were electrophoresed through a $1 \%$ agarose-formaldehyde gel and transferred to nitrocellulose or Nytran filters (Schleicher \& Schuell, Keene, NH). After hybridization with a ${ }^{32} \mathrm{P}$-labeled plasmid DNA $\left(42^{\circ} \mathrm{C}, 50 \%\right.$ formamide, $5 \times$ SSC, $10 \%$ dextran sulfate), these blots were washed at $65^{\circ} \mathrm{C}$ in $0.2 \times$ SSC, $1.0 \%$ SDS and exposed to X-OMAT AR film with a lightening plus intensifying screen at $-70^{\circ} \mathrm{C}$. Rehybridization of filters was performed as described above after treating Nytran filters for $1 \mathrm{~h}$ in $50 \%$ formamide, $1 \times \mathrm{SSC}$ at $75^{\circ} \mathrm{C}$ or nitrocellulose filters for $15 \mathrm{~min}$ in boiling $0.1 \times$ SSC, $0.1 \%$ SDS.

Protooncogene containing plasmid DNA probes. Recombinant plasmid DNA probes containing the following protooncogenes were ${ }^{32} \mathrm{P}$-radiolabeled by either nick-translation (30) or the preparation of a single strand specific M13 probe by the method of $\mathrm{Hu}$ and Messing (31): c-myb, a $2.2 \mathrm{kbp}$ Hae III DNA fragment probe of a human c-myb cDNA plasmid (kindly provided by J. Frederic Mushinski, NCI/NIH); N-myc-pNB-1 DNA (32) or pC7 (unpublished plasmid of E. Flamm and $M$. A. Israel containing a 2.1-kb pair $\mathrm{cDNA}$ insert with sequence homology to human genomic N-myc nucleotides $1045-3179$ as described by Kohl et al. [33]); c-myc a $1.3 \mathrm{~kb}$ pair ClaI-Eco R1 fragment of pMC41-3RC (34); and c-cts-1, an 800-bp Hind III fragment of pKH47 (35).

\section{Results}

Histopathology of NE and NB-N. Primitive NE and NB-N are tumors of the peripheral nervous system that exhibit subtle, though unmistakable features of neuronal differentiation. A histologic comparison of these tumors and cell lines derived from them is shown in Fig. 1. Light microscopic examination of a NB-N tumor $(A)$ and a NE tumor $(E)$ reveals clusters of morphologically undifferentiated, cohesive, round cells in which few if any distinguishing characteristics such as Homer Wright rosettes (4) or ganglion cells are seen. In tissue culture, cell lines derived from NB-N and NE tumors $(B, F$, respectively) are substrate-adherent with neuritic processes characteristic of neural cells in culture. Low magnification electron microscopy (EM, uranylacetate/lead citrate, $\times 7,000)$ of NB-N and NE cell lines reveals ultrastructural features of neural differentiation including abortive neuritic processes $(C, G$, re- spectively) and, at higher magnification, the presence of neurosecretory vesicles $(D, H$, respectively) suggesting the presence of neurotransmitters (EM as above, $\times 15,000$; inset, $\times 30,000$ ).

Neurotransmitter biosynthetic enzymes. An interesting feature of NB cell lines is their ability to express biochemical properties of normal neuronal cells (36). An analysis of the pattern of neurotransmitter biosynthetic enzyme activities revealed a striking difference between NE and NB-N (Table I). We found cell lines from NE to be characterized by high levels of CAT activity, the rate-limiting enzyme in the biosynthesis of acetylcholine, a neurotransmitter in the parasympathetic branch of the PNS (11). However, we detected no activity in these cell lines of either DBH or tyrosine hydroxylase (TH), cathecholamine biosynthetic enzymes that are highly expressed in the sympathetic branch of the PNS. In contrast, the NB-N cell lines we examined contained high levels of TH and DBH but no detectable CAT activity.

While most NB cell lines have been reported to express only neurotransmitter biosynthetic enzymes associated with an adrenergic phenotype, some express a mixed pattern of neurotransmitter biosynthetic enzyme activities (36). Two cell lines, SK-N-MC and CHP-100, had previously been reported to express CAT uniquely $(24,36)$. Although diagnosed originally as neuroblastoma, the patients from whom SK-N-MC and CHP-100 were derived had clinical histories $(24,36)$ that can now be recognized as typical of NE (4). Furthermore, cytogenetic examination of these cell lines demonstrates evidence of a $t(11 ; 22)$ chromosomal rearrangement indicating they are NE rather than NB tumor cell lines (22). Examination of the neurotransmitter biosynthetic enzymes in these two cell lines as well as in three additional NE cell lines revealed a concordance between the cholinergic phenotype and $t(11 ; 22)$ (Table I). In contrast, none of the 13 adrenergic or mixed adrenergic/cholinergic NB-N cell lines we examined or that are reported in the literature contain this cytogenetic alteration (19-25, 35-38). The association of CAT expression and the $t(11 ; 22)$ in NE cell lines provides further evidence that NE is a biologically distinct entity from NB-N.

Structure of $N$-myc gene. One of the most common cytogenetic alterations found in NB-N cell lines are homogeneously staining regions and double minute chromosomes $(23,37,38)$.

Table I. Neurotransmitter Biosynthetic Enzymes

\begin{tabular}{|c|c|c|c|c|c|c|c|}
\hline \multirow[b]{2}{*}{ Cell line } & & \multicolumn{2}{|c|}{ Tyrosine-hydroxylase } & \multicolumn{2}{|c|}{ Dopamine-B-hydroxylase } & \multicolumn{2}{|c|}{ Choline-acetyltransferase } \\
\hline & & Expt. 1 & Expt. 2 & Expt. 1 & Expt. 2 & Expt. 1 & Expt. 2 \\
\hline & & $n m o l / h / m g *$ & & $n m o l / h / m$ & & $n m o l / h / m g$ & \\
\hline N1000 & NE & $0.02 \pm 0.01^{\ddagger}$ & $\mathrm{ND}^{\S}$ & ND & ND & $12.0 \pm 7.9$ & $94.4 \pm 41.5$ \\
\hline $\mathrm{TC} 32$ & NE & $0.02 \pm 0.01$ & ND & ND & ND & $7.5 \pm 0.1$ & $37.6 \pm 15.5$ \\
\hline SK-N-MC & $\mathrm{NE}$ & ND & ND & ND & ND & $2.0 \pm 0.4$ & $7.0 \pm 1.6$ \\
\hline CHP-100 & NE & ND & ND & ND & ND & $4.1 \pm 0.7$ & $7.7 \pm 2.2$ \\
\hline N1008 & NE & $\mathrm{NT}^{\mathrm{d}}$ & ND & ND & ND & NT & $2.9 \pm 0.5$ \\
\hline SMS-KCNR & NB-N & $0.95 \pm 0.20$ & $0.50 \pm 0.1$ & $1.8 \pm 0.1$ & $2.1 \pm 0.8$ & ND & ND \\
\hline LA-N-5 & NB-N & $0.20 \pm 0.01$ & NT & $0.4 \pm 0.6$ & NT & ND & NT \\
\hline IMR-32 & NB-N & $0.74 \pm 0.10$ & $1.8 \pm 0.3$ & $0.8 \pm 0.1$ & ND & ND & ND \\
\hline
\end{tabular}

The activity of the neurotransmitter biosynthetic enzymes, TH, DBH, and CAT is expressed as amount of product formed per hour per milligram of protein. The values represent the mean of triplicate assays on replicate cultures. ${ }^{*}$ Activity in nanomoles of product formed per hour per milligram of protein. ${ }^{\ddagger}$ Mean \pm SEM of triplicate assays of each experiment. ${ }^{\S}$ Not detected. 

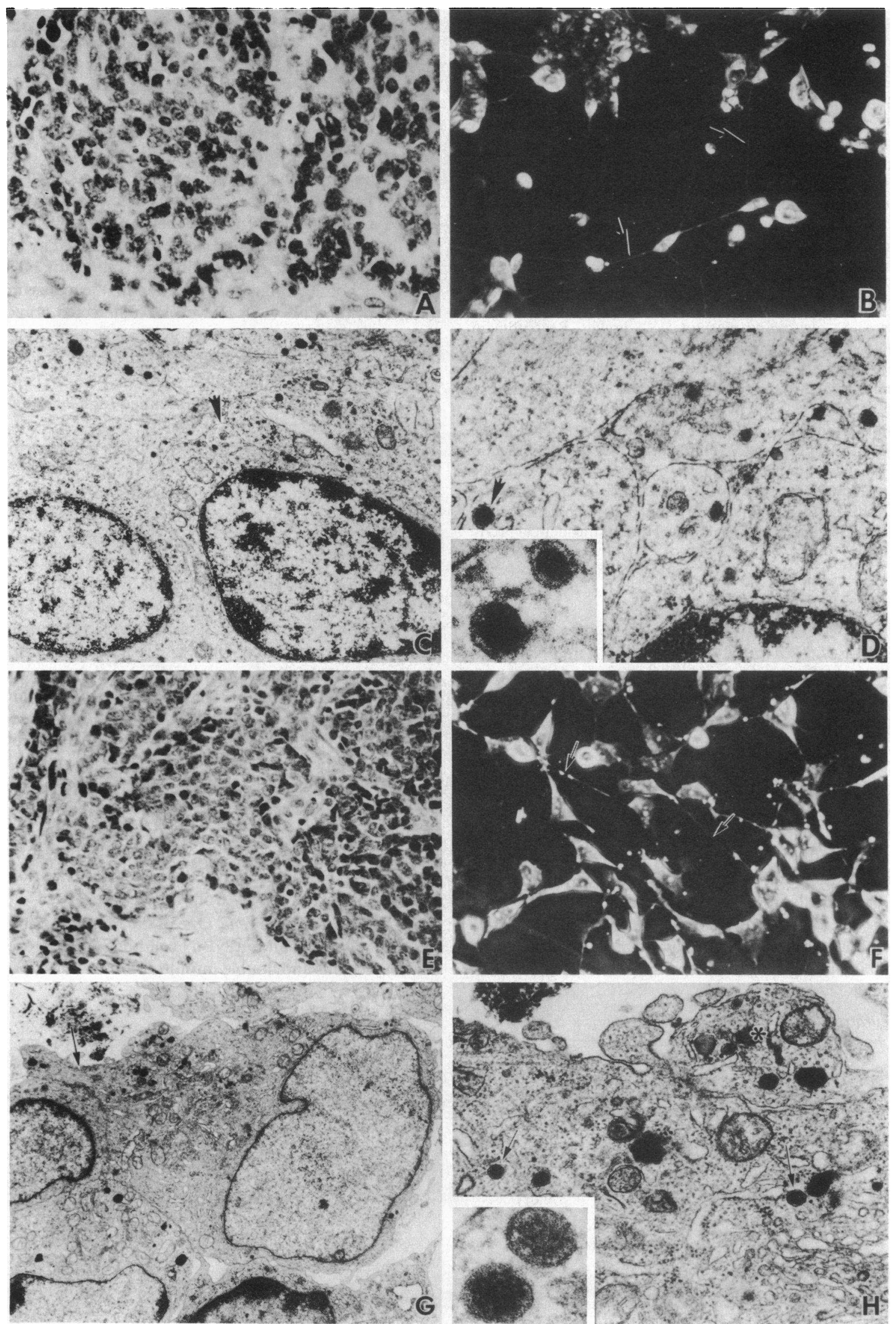

Figure 1. Histopathologic evaluation of NE and NB-N. NE(TC32) and NB-N(KCN) cell lines and tumor tissue were evaluated: by light microscopy of NB-N $(A)$ and NE $(E)$ (hematoxylin \& eosin, $\times 400$ ); by phase-contrast microscopy of NB-N $(B)$ and NE $(F)(\times 200)$; by

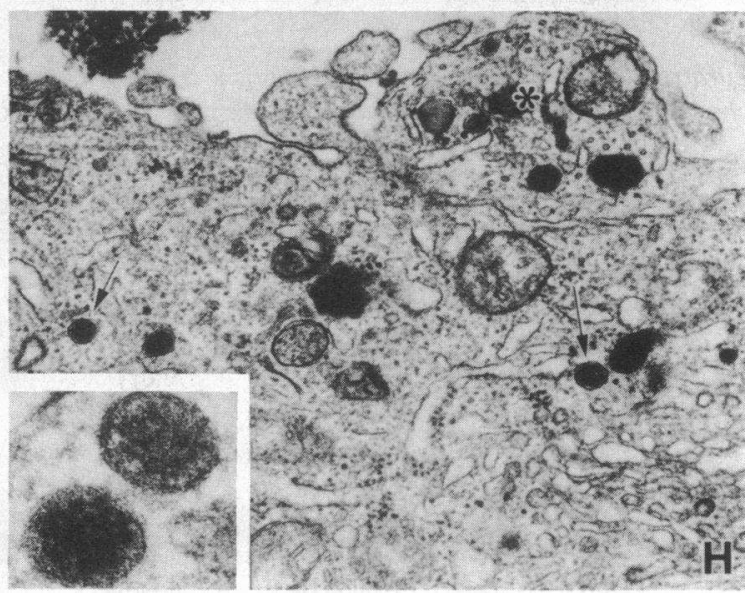

low magnification electron microscopy (EM) of NB-N $(C)$ and NE $(G)(E M$, uranyl acetate/lead citrate, $\times 7,000)$; and by high magnifcation EM of NB-N $(D)$ and NE $(H)(E M$, uranyl acetate/lead citrate, $\times 15,000$; inset, $\times 30,000$ ). 


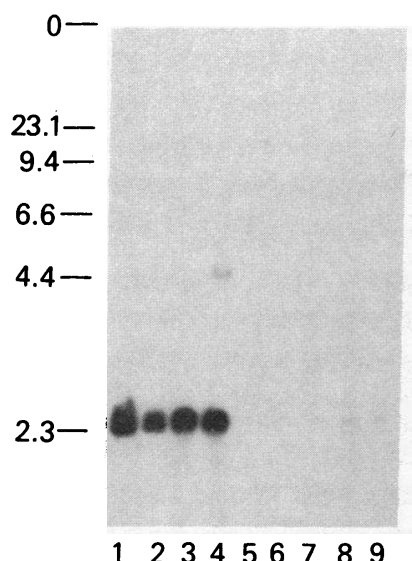

123456789

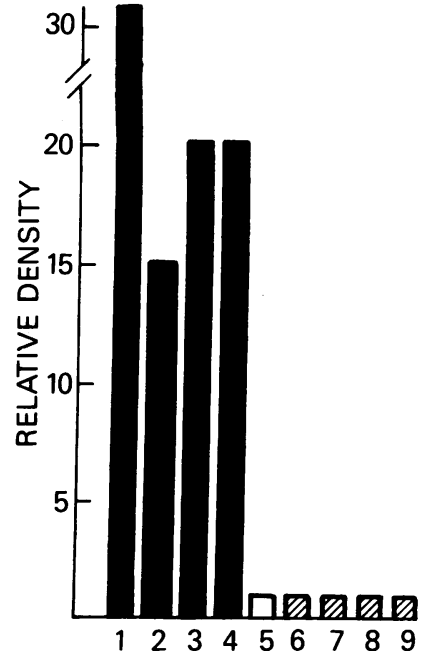

$\begin{array}{lllllllll}1 & 2 & 3 & 4 & 5 & 6 & 7 & 8 & 9\end{array}$

Figure 2. Southern blot analysis of N-myc gene structure in NE and NB-N. Lanes 1-4 are NB-N cell lines (1) SMS-KCNR, (2) IMR-32, (3) SMS-SAN, and (4) LA-N-5. Lanes 6-9 are NE cell lines (6) TC-32, (7) N1000, (8) SK-N-MC and (9) CHP-100. Lane 5 is DNA isolated from normal brain obtained at autopsy. To the right of $(A)$ is a graphic representation of the relative $\mathrm{N}-m y c$ gene copy number as determined by quantitative densitometric scanning of comparable experiments on appropriately diluted samples of DNA.

In several cell lines, these structures have been shown to contain amplification of the $\mathrm{N}-m y c$ gene $(32,39)$. $\mathrm{N}-m y c$ is structurally and functionally related to the protooncogene c-myc $(33,40-42)$ and is expressed at discrete stages of murine development $(43,44)$. To determine whether $\mathrm{N}$-myc amplification also occurred in NE tumor cell lines, we examined the level of $\mathrm{N}-m y c$ amplification in adrenergic or adrenergic/cholinergic NB-N and cholinergic NE cell lines by Southern blot analysis (Fig. 2). This experiment demonstrates that in contrast to NB-N cell lines, NE cell lines contained only a single copy of the $\mathrm{N}-m y c$ gene. To our knowledge, the $t(11 ; 22)$ is only seen in cholinergic cell lines, and the cholinergic/t $(11 ; 22)$ cell lines invariably had a single copy of $\mathrm{N}-m y c$ (22, this paper, and McKeon, C., C. Thiele, R. Ross, M. Kwan, T. Triche, J. Miser,

and M. A. Israel, manuscript submitted for publication.). Conversely, with a single exception, published NB cell lines show a concordance between the expression of a predominantly adrenergic phenotype and amplification of $\mathrm{N}-m y c(19-25,32$, 39). The exception, SK-N-SH, is an adrenergic NB cell line (23) that contains neither amplified $\mathrm{N}$-myc sequences $(32,39)$ nor a $t(11 ; 22)(23)$, although it does contain another genetic alteration, an activated $\mathrm{N}$-ras gene (45). This cell line may define another subset of NB tumors.

Protooncogene expression. Since protooncogenes are known to be regulated in normal tissues in a lineage and differentiation-stage specific manner $(11,15)$, we examined the expression of several protooncogenes in NE and NB-N cell lines. We anticipated similarities in the pattern of protooncogene expression since both NE and NB-N are of neural origin. However, the differences in neurotransmitter biosynthetic enzyme activity between NE and NB-N suggested that they might be tumors of cells corresponding to different pathways or stages of PNS tissue differentiation and might differentially express some protooncogenes.

Previously, we have reported that neither NE nor NB-N cell lines express detectable c-sis transcripts (46), while both contain high levels of pp60c-src kinase activity $(47,48)$. In this study, we examined the expression of $c-m y b$, another protooncogene with a highly restricted pattern of expression that is regulated during the differentiation of hematopoetic cells (49). Equivalent levels of c-myb RNA were detected in 7/7 PN and 6/6 NB-N cell lines (Table II). A representative Northern blot demonstrating c-myb expression in these cell lines is shown in Fig. $3 A$.

Since some retinoblastoma tumors express high levels of $\mathrm{N}-m y c$ RNA without amplification of the $\mathrm{N}-m y c$ gene (50), we studied the expression of $\mathrm{N}-m y c$ in NE and NB-N. We found that NE cell lines express N-myc (Table II; Fig. 3 B) at low levels, which are comparable to that detected in SK-N-SH (data not shown), a NB cell line that has a single copy of the $\mathrm{N}-m y c$ gene per haploid genome $(32,39)$. As expected, NB-N cell lines express high levels of $\mathrm{N}-m y c(51)$. We also evaluated these cell lines for the expression of $c-m y c$. The Northern blot shown in $B$ was rehybridized with ${ }^{32} \mathrm{P}$-labeled c-myc DNA and the results are shown in Fig. $3 C$. In sharp contrast to the NB-N

Table II. Contrasting Genetic Features of Neuroepithelioma and Neuroblastoma-N

\begin{tabular}{|c|c|c|c|c|c|c|c|c|c|c|c|c|c|}
\hline \multirow[b]{2}{*}{ Tumor cell lines examined } & \multicolumn{6}{|c|}{ Neuroblastoma-N } & \multicolumn{7}{|c|}{ Neuroepithelioma } \\
\hline & $\begin{array}{l}\text { SMS- } \\
\text { KCN }\end{array}$ & $\begin{array}{l}\text { SMS- } \\
\text { KCNR }\end{array}$ & $\begin{array}{l}\text { SMS- } \\
\text { KAN }\end{array}$ & $\begin{array}{l}\text { SMS- } \\
\text { SAN }\end{array}$ & $\begin{array}{l}\text { LA- } \\
\text { N-5 }\end{array}$ & $\begin{array}{l}\text { IMR- } \\
32\end{array}$ & N1000 & TC32 & N1008 & N1016 & N1043 & $\begin{array}{l}\text { SK- } \\
\text { N-MC }\end{array}$ & $\begin{array}{l}\text { CHP- } \\
100\end{array}$ \\
\hline \multicolumn{14}{|l|}{ Cytogenetic alterations } \\
\hline$t(11 ; 22)$ & - & - & - & - & - & - & + & + & + & + & $+^{*}$ & + & + \\
\hline N-myc amplification & + & + & + & + & + & + & - & - & - & - & - & - & - \\
\hline \multicolumn{14}{|l|}{$\begin{array}{l}\text { Relative protooncogene } \\
\text { expression }\end{array}$} \\
\hline$c-m y b$ & $+^{\ddagger}$ & + & + & + & + & + & + & + & + & + & + & + & + \\
\hline $\mathrm{N}-m y c$ & $++^{\S}$ & ++ & ++ & ++ & ++ & ++ & + & + & + & + & + & + & + \\
\hline$c-m y c$ & -11 & - & - & - & - & - & ++ & ++ & ++ & ++ & ++ & ++ & ++ \\
\hline c-ets-1 & + & + & + & + & + & + & + & - & -1 & - & - & + & - \\
\hline
\end{tabular}

* Unpublished results J. Whang-Peng and M. Israel. $\quad+$ + Detected in cytoplasmic RNA preparations. $\$++10-100$-fold higher than.+

" - Not detected in cytoplasmic RNA preparations. 'c-ets-1 expression can be detected in poly (A)+ selected RNA. 

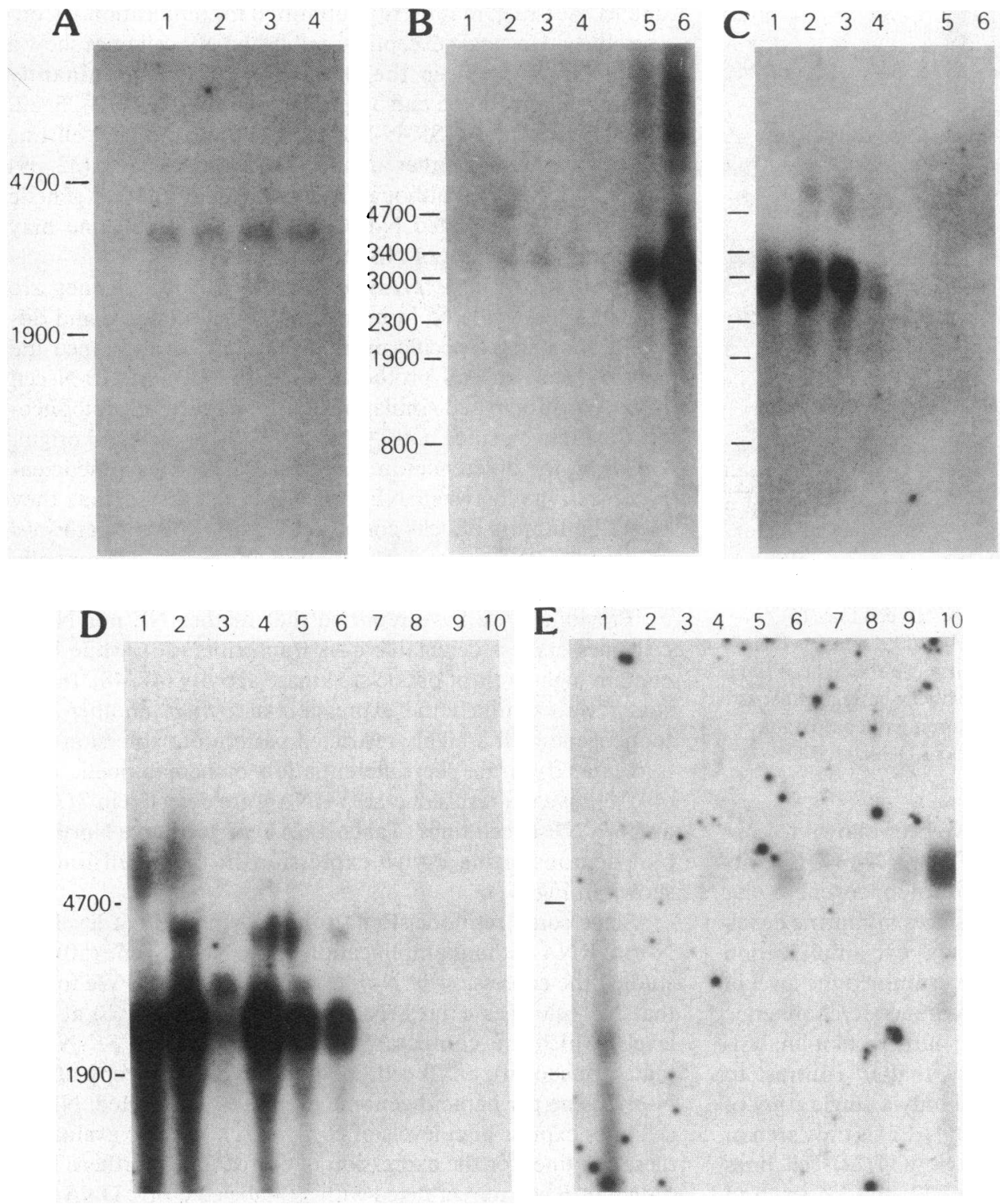

Figure 3. Northern blot analysis of the expression of protooncogenes in NE and NB-N cell lines. $(A)$ Northern blot analysis of $2 \mu \mathrm{g}$ of poly(A)+ RNA from NE cell lines (1) TC-32 and (2) CHP-100 and NB cell lines (3) SMS-KAN and (4) SMS-KCNR hybridized to a ${ }^{32} \mathrm{P}$-labeled $2.2 \mathrm{~kb}$ Hae III DNA fragment probe of a human c-myb cDNA plasmid. (B) Northern blot analysis of poly(A)+ RNA from NE and NB-N cell lines hybridized with ${ }^{32} \mathrm{P}$-labeled N-myc plasmid probe, pNB-1 (5). The lanes contain cytoplasmic poly(A)+ RNA from NE cell lines (I) $15 \mu \mathrm{g}$ TC32, (2) $15 \mu \mathrm{g} \mathrm{CHP-100,} \mathrm{(3)} 15 \mu \mathrm{g}$ SK-N-MC and (4) $5 \mu \mathrm{g} \mathrm{N1000} \mathrm{and}$ a NB-N cell line: (5) $2 \mu \mathrm{g}$ SMS$\mathrm{KCN},(6) 15 \mu \mathrm{g} \mathrm{SMS-KCN.} \mathrm{(C)} \mathrm{Re-}$ hybridization of the previous nitrocellose filter with ${ }^{32} \mathrm{P}$-labeled $1.3 \mathrm{~kb}$ ClaI-Eco RI fragment of c-myc plasmid, pMC41-3RC (35). (D) Northern analysis of $35 \mu \mathrm{g}$ of cytoplasmic RNA from NE and NB-N cell lines blotted and hybridized with the ${ }^{32} \mathrm{P}$ labeled c-myc DNA fragment probe previously described. The lanes correspond to NE cell lines (1) N1000, (2) N1008, (3) N1016, (4) SK-NMC, (5) N1043, a NB cell line (6) SK-N-SH, and NB-N cell lines (7) SMS-KAN, (8) SMS-SAN, (9)

LA-N-5 and (10) SMS-KCNR. (E) The Nytran filter utilized in $D$ was rehybridized to an 800 bp Hind III fragment of a c-ets-1 plasmid DNA. cell line studied, NE cell lines express high levels of c-myc mRNA. Fig. $3 D$, shows a comparison of the level of c-myc expression in five NE cell lines and four additional NB-N cell lines. The high levels of $c-m y c$ in NE may be due to structural alterations in that gene since cytogenetic analysis of NE cell lines (22) show a supernumery chromosome 8 in N1000, N1008, and SK-N-MC and Kohl et al. (39) report amplification of c-myc in CHP-100 and a subclone of SK-N-MC, SK-MC-IXC. In addition to the $2.7 \mathrm{~kb}$ c-myc mRNA species, some NE cell lines express an additional $3.1 \mathrm{~kb}$ RNA species that is recognized by the c-myc DNA probe. This RNA species is expressed at high levels in the NE cell line $\mathrm{N} 1016(D$, lane 3$)$, while it is not detected in NB-N cell lines or in the SK-N-SH NB cell line ( $D$, lane 6$)$. The 3.1-kb mRNA species does not cross hybridize with other members of the $m y c$ gene family (Thiele, C., unpublished observations). While it is possible that this mRNA species as well as the larger mRNA species seen in some lanes represent c-myc precursor mRNAs, we have detected a rearrangement in the c-myc gene in N1016, which may account for the 3.1-kb mRNA species (McKeon, C., C.
Thiele, M. Israel, unpublished results). This is currently under investigation.

The altered regulation of protooncogene expression has been implicated in the etiology of both experimentally induced and sporadically occurring tumors (10-13). One proposed mechanism mediating the altered regulation of a protooncogene is its translocation to another chromosome $(52,53)$. Since NE contains a $t(11 ; 22)(q 24 ; q 12)$ and the c-ets-1 protooncogene has been mapped to $11 \mathrm{q} 24$ (35), we evaluated NE and NB-N cell lines for expression of c-ets-1. We detected moderate levels of c-ets-1 mRNA in 6/6 of the NB-N cell lines we examined, while only $3 / 8 \mathrm{NE}$ cell lines we examined expressed detectable levels of c-ets-1 RNA (Table II, Fig. $3 E$, our unpublished data). In a more critical examination of the NE cell lines which did not have detectable c-ets- 1 expression, we evaluated $15 \mu \mathrm{g}$ of poly(A)+ RNA and were able to detect c-ets- 1 expression in N1008 (data not shown) but not TC32 or CHP100 (Fig. 3 B).

While tumor cell lines are particularly useful in studying genetic alterations in pure populations of malignant cells, we 
also examined the pattern of protooncogene expression in NE and NB-N tumor tissue. In some cases, tissue was available from tumors that had given rise to cell lines that we have examined in this report. The relative levels and pattern of $\mathrm{N}-m y c$ and c-myc protooncogene expression (Fig. $4 A, B$, respectively) in these tumor tissues are consistent with those seen in the cell lines from the corresponding tumor type. Examination of these same specimens for c-ets-1 expression (Fig. $4 C$ ) indicated that each of the NB-N tumor samples expressed c-ets-1 RNA, a finding that complements the observation that this protooncogene is expressed in all cell lines derived from NB-N. We also detected c-ets-1 expression in 1 of 2 NE tumor tissues (Fig. $4 C$ ). In other experiments, we have detected c-ets-1 expression in four of five additional NE tumor tissues (data not shown). These data contrast with the absence of detectable c-ets- 1 expression in most NE cell lines, although their interpretation is complicated by the known expression of c-ets- 1 in stromal and vascular tissues $(54,55)$ that are present in all tumor specimens.

\section{Discussion}

Protooncogene expression in tumors reflects normal cellular processes associated with proliferation, specific stages of tissue differentiation, and perhaps other biologic features that we do not yet appreciate. However, protooncogene expression may also denote underlying genetic alterations that either directly cause or occur as a consequence of tumorigenesis. Our findings that c-src protein kinase activity and the pattern of c-sis and $c-m y b$ expression are constant and highly predictable for both NB and NE may suggest that these genes are regulated in a manner that reflects a similar growth or developmental state.

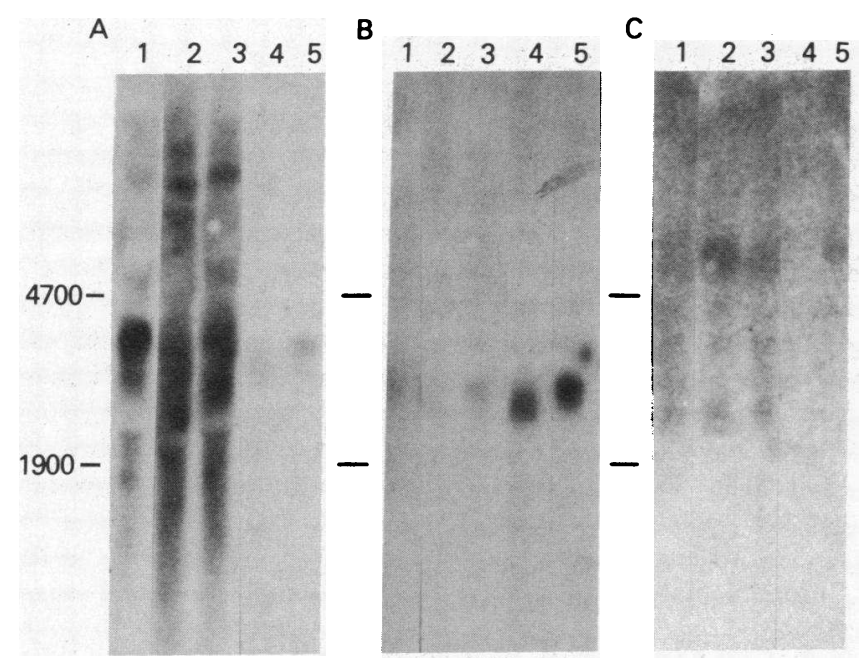

Figure 4. Protooncogene expression in NE and NB-N tumor tissue. Northern blot analysis of $35 \mu \mathrm{g}$ of total RNA from selected NE and NB tumor tissue [lanes 1 GSN, 2 KCN, 3 KAN (The cell lines SMS$\mathrm{KCN}$ and SMS-KAN were derived from the tumor tissue $\mathrm{KCN}$ and KAN, respectively.)] and NE tumor tissue [lane 4 19-7 (The cell line N1016 was derived from this tumor tissue.) and 5 18-13]. (A) The blot was hybridized to a Messing (31) ${ }^{32} \mathrm{P}$-labeled pC7 N-myc plasmid DNA. (B) Rehybridization with a nick-translated ${ }^{32} \mathrm{P}$-labeled 1.3 kb CLaI-Eco RI fragment of c-myc plasmid DNA. $(C)$ Rehybridization with a nick-translated ${ }^{32} \mathrm{P}$-labeled $800 \mathrm{bp}$ Hind III DNA fragment of a c-ets-1 plasmid DNA.
In one group of NB tumors we studied, NB-N, N-myc expression was predictably high. However, we found it remarkable that without exception the level of $c-m y c$ expression was high in NE, while the level of $\mathrm{N}-m y c$ expression was low. The altered regulation of one or both of these $m y c$ family genes could be important in the etiology of these tumors. The amplification of N-myc DNA in NB-N also supports this possibility. Alternatively, different stages in PNS differentiation may be associated with high levels of expression of these protooncogenes, and these tumors may arise in tissues corresponding to these different stages.

The detection of c-ets-1 RNA in each of the NB-N tissue specimens we examined is compatible with the possibility that this gene is also expressed in the normal cell from which this tumor arises. However, of the six protooncogenes we have examined, the only one that had an unpredictable pattern of expression was c-ets-1, and this occurred only in NE and not NB. The location of c-ets-1 close to the $t(11 ; 22)$ in NE, suggests that alterations in this gene may have an important role in the development of this malignancy. If such a role were mediated by both regulatory and structural alterations in this gene, as has been hypothesized for the translocated c-myc gene in Burkitt's lymphoma (52), it seems likely that an unpredictable pattern of expression would be found.

Although NB-N and NE appear histologically indistinguishable and have usually been considered as a single pathologic entity, there are clearly cytogenetic and biochemical differences indicating that NE and NB-N are different tumors of the PNS. One striking biochemical difference between NE and NB-N is in the pattern of their neurotransmitter biosynthetic enzyme activities. NE express enzyme activities associated with cholinergic neurons, while NB-N express enzyme activities that are predominantly associated with adrenergic neurons. Another difference is our finding of highly predictable and distinct patterns of protooncogene expression in these tumors that suggests that patterns of protooncogene expression may also distinguish closely related tumors. The similarities in the patterns of protooncogene expression in NB-N and NE are compatible with the origin of these tumors in cells that are ontogenetically related: the differences may reflect unique biologic features of the precise cell of origin or perhaps the genetic events involved in the development of the malignancy. Of particular interest is the finding that in different samples of each tumor type, the pattern of protooncogene expression is largely invariant while marking different biologic entities among these histopathologically indistinguishable tumors. Indeed, other investigators have presented evidence compatible with the possibility that protooncogene expression may define genetically distinct forms of colon cancer (53). We propose that if patterns of protooncogene expression identify homogeneous subgroups among tumors now recognized to be heterogeneous in their clinical behavior and therapeutic responsiveness, such patterns may be useful as tumor markers to more effectively stratify tumors for study and cancer patients for therapy.

\section{References}

1. Brodeur, G. M., R. C. Seeger, and M. Schwab. 1984. Amplification of N-myc in untreated human neuroblastomas correlates with advanced disease stage. Science (Wash. DC). 224:1121-1124.

2. Seeger, R. C., G. M. Brodeur, H. Sather, A. Dalton, S. Siegel, 
K. Y. Wong, and D. Hammond. 1985. Association of multiple copies of the $\mathrm{N}$-myc oncogene with rapid progression of neuroblastoma. $N$. Engl. J. Med. 313:1111-1116.

3. Whang-Peng, J., T. J. Triche, T. Knutsen, J. Miser, E. C. Douglass, and M. A. Israel. 1984. Chromosome translocation in peripheral neuroepithelioma. N. Engl. J. Med. 311:584-585.

4. Triche, T. J., F. B. Askin, and J. M. Kissane. 1986. Neuroblastoma, Ewing's sarcoma, and the differential diagnosis of small-, round-, blue-cell tumors. In Pathology of Neoplasia in Children and Adolescents. M. Finegold, editor. W. B. Saunders, Philadelphia. 145-195.

5. Mackay, B., M. A. Luna, and J. J. Butler. 1976. Adult neuroblastoma. Electron microscopic observations in nine cases. Cancer. 37:1334-1351.

6. Aleshire, S. L., A. D. Glick, V. E. Cruz, C. A. Bradley, and F. F Parl. 1985. Neuroblastoma in adults. Pathologic findings and clinical outcome. Arch. Pathol. Lab. Med. 109:352-356.

7. Hashimoto, H., M. Enjoji, T. Nakajima, et al. 1983. Malignant neuropithelioma (peripheral neuroblastoma): A clinico-pathologic study of 15 cases. J. Surg. Pathol. 7:309-318.

8. Bolen, J. W., and D. Thorning. 1980. Peripheral neuroepithelioma: A light and electron microscopic study. Cancer. 46:2456-2462.

9. Donner, L., T. J. Triche, M. A. Israel, R. C. Seeger, and C. P. Reynolds. 1985. A panel of monoclonal antibodies which discriminate neuroblastoma from Ewing's sarcoma, thabdomyosarcoma, neuroepithelioma, and hematopoietic malignancies: In Advances in Neuroblastoma Research. A. Evans, G. D'Anglo, and R. C. Seeger, editors. Alan R. Liss, Inc., New York. 347-366.

10. Bishop, J. M. 1983. Cellular oncogenes and retroviruses. Annu. Rev. Biochem. 52:301-54.

11. Varmus, H. E. 1984. The molecular genetics of cellular oncogenes. Annu. Rev. Gen. 18:553-612.

12. Hunter, T. 1985. Oncogenes and proto-oncogenes: How do they differ? J. Natl. Cancer Inst. 73:773-785.

13. Hayward, W. S., B. C. Neel, and S. M. Astrin. 1981. Activation of a cellular oncogene by promoter insertion in ALV-induced lymphoid leukosis. Nature (Lond.). 290:475-480.

14. Taparowsky, E., Y. Suard, O. Fassano, K. Shimizu, M. Goldfarb, and M. Wigler. 1982. Activation of T24 bladder carcinoma transforming gene is linked to a single amino acid change. Nature (Lond.). 300:762-765.

15. Slamon, D. J., and M. J. Cline. 1984. Expression of cellular oncogenes during embryonic and fetal development of the mouse. Proc. Natl. Acad. Sci. USA. 81:7141-7145.

16. Eva, A., K. C. Robbins, P. R. Andersen, A. Srinivasan, S. R. Tronick, P. Reddy, N. W. Ellmore, A. T. Galen, J. A. Lautenberger, T. S. Papas; E. H. Westin, F. Wong-Staal, and R. C. Gallo. 1982. Cellular genes analogous to retroviral onc genes are transcribed in human tumour cells. Nature (Lond.). 295:116-119.

17. Westin, E. H., F. Wong-Staal, E. P. Gelmann, R. Dalla Favera, T. S. Papas, J. A. Lautenberger, A. Eva, E. P. Reddy, S. R. Tronick, S. A. Aaronson, and R. C. Gallo: 1982. Expression of cellular homologues of retroviral onc genes in human hematopoietic cells. Proc. Natl. Acad. Sci. USA. 79:2490-2494.

18. Slamon, D. J., J. B. deKernion, I. M. Verma, and M. J. Cline. 1984. Expression of cellular oncogenes in human malignancies. Science (Wash. D.C.). 224:256-262.

19. Reynolds, C. P., J. L. Beidler, B. A. Spengler, D. A. Reynolds, R. A. Ross, R. A. Frenkel, and R. G. Smith. 1986. Characterization of human neuroblastoma cells lines established before and after therapy. J. Natl. Cancer Inst. 76:375-387.

20. West, G. J., J. Uki, H. R. Herschman, and R. C. Seeger. 1977. Adrenergic, cholinergic and inactive human neuroblastoma cell lines with the action-potential $\mathrm{Na}+$ ionophore. Cancer Res. 37:1372-1376.

21. Tumilowicz, J. J., W. W. Nichols, J. J. Cholan, and A. E. Greene. 1970. Definition of a continuous human cell line derived from neuroblastoma. Cancer Res. 30:2110-2118.

22. Whang-Peng, J., T. J. Triche, T. Knutsen, J. Miser, S. Kao-
Shan, S. Tsai, and M. A. Israel. 1986. Cytogenetic characterization of selected small round cell tumors of childhood. Cancer Genet. Cytogenet. 21:185-208.

23. Biedler, J. L., L. Helson, and B. A. Spengler. 1973. Morphology and growth, tumourgenicity and cytogenetics of human neuroblastoma cells in continuous culture. Cancer Res. 33:2643-2649.

24. Schlesinger, H. R., J. M. Gerson, P. S. Moorhead, H. Maguire, K. Hummler. 1976. Establishment and Characterization of Human Neuroblastoma Cell Lines. Cancer Res. 36:3094-3100.

25. Ross, R. A., J. L. Biedler, B. A. Spengler, and D. J. Reis. 1981. Neurotransmitter-synthesizing enzymes in 14 human neuroblastoma cell lines. Cell. Mol. Neurobiol. 1:301-311.

26. Israel, M. A., D. F. Vanderryn, M. L. Mettzer, and M. A. Martin. 1980. Characterization of polyoma viral DNA sequences in polyoma induced hamster tumor cell lines. J. Biol. Chem. 255:3798.

27. Southern, E. M. 1975. Detection of specific sequences among DNA fragments separated by gel electrophoresis. J. Mol. Biol. 98:503.

28. Thiele, C. J., C. P. Reynolds, and M. A. Israel. 1985. Decreased expression of $\mathrm{N}$-myc precedes retinoic acid induced morphological differentiation of human neuroblastoma. Nature (Lond.). 313:404406.

29. Chirgwin, J. M., E. A. Przybyla, R. J. MacDonald, and W. J. Rutter. 1979. Isolation of biologically active ribonucleic acid from sources enriched in ribonuclease. Biochemistry. 65:718-749.

30. Rigby, P. W., M. Dieckmann, C. Rhodes, and P. Berg. 1977. Labeling deoxyribonucleic acid to high specific activity in vitro by nick translation with DNA polymerase I. J. Mol. Biol. 113(1):237-251.

31. Hu, N., and J. Messing. 1982. The making of strand-specific M13 probes. Gene. 17:271-277.

32. Schwab, M., K. Alitalo, K. H. Klempnauer, H. E. Varmys, J. M. Bishop, F. Gilbert, G. Brodeur, M. Goldstein, and J. Trent. 1983. Amplified DNA with limited homology to myc cellular oncogene is shared by human neuroblastoma cell lines and a neuroblastoma tumour. Nature (Lond.). 305:245-248.

33. Kohl, N. E., E. Legouy, R. A. DePinho, P. D. Nisen, R. K. Smith, C. E. Gee, and F. W. Alt. 1986. Human N-myc is closely related in organization and nucleotide sequence to c-myc. Nature (Lond.). 319:73-77.

34. Dalla Favera, R., E. P. Gelman, S. Martinotti, G. Franchini, T. Papas, R. C. Gallo, and F. Wang-Staal. 1982. Cloning and characterization of different human sequences related to the oncogene ( $\mathrm{v}$-myc) of avian myelacytomatosis virus (MC29). Proc. Natl. Acad. Sci. USA. 79:6497-6501.

35. deTaisne, C., A. Gegonne, and D. Stehelin. 1984. Chromosomal localization of the human proto-oncogene c-ets. Nature (Lond.). 210:581-583.

36. Biedler, J. L., S. Roffler-Tarlov, M. Schachner, and L. S. Freedman. 1978. Multiple Neurotransmitter Synthesis by Human Neuroblastoma Cell Lines and Clones. Cancer Res. 38:3751-3757.

37. Brodeur, G. M., A. A. Green, F. A. Hayes, K. J. Williams, D. L. Williams; and A. A. Tsiatis. 1981. Cytogenetic features of human neuroblastoma and cell lines. Cancer Res. 41:4678-4686.

38. Brodeur, G. M., G. S. Sekhon, and M. N. Goldstein. 1970. Chromosomal aberrations in human neuroblastomas. Cancer. 40:2256-2263.

39. Kohl, N. E., N. Kanda, R. R. Schreck, G. Bruns, S. A. Latt, F. Gildbert, and F. W. Alt. 1983. Transposition and amplification of oncogene-related sequences in human neuroblastomas. Cell. 35:359367.

40. Schwab, M., H. E. Varmus, and J. M. Bishop. 1985. Human $\mathrm{N}$-myc contributes to neoplastic transformation of mammalian cells in culture. Nature (Lond.). 316:160-162.

41. Yancopoulus, G. D., P. D. Nisen, A. Tesfaye, N. E. Kohl, M. P. Goldfarb, and F. W. Alt. 1985. N-myc can cooperate with ras to transform normal cells in culture. Proc. Natl. Acad. Sci. USA. 82:5455-5459.

42. DePinho, R. A., E. Legouy, L. B. Feldman, N. E. Kohl, G. D. 
Yancopoulos, and F. W. Alt. 1986. Structure and expression of the murine n-myc gene. Proc. Natl. Acad. Sci. USA. 83:1827-1831.

43. Jakobovits, A., M. Schwab, J. M. Bishop, and G. R. Martin. 1985. Expression of n-myc in teratocarcinoma stem cells and mouse embryos. Nature (Lond.). 318:188-191.

44. Zimmerman, K. A., G. D. Yancopoulos, R. G. Collum, R. K. Smith, N. E. Kohl, K. A. Denis, M. M. Nau, O. N. Witte, D. ToranAllerand, C. E. Gee, J. D. Minna, and F. W. Alt. 1986. Differential expression of myc family genes during murine development. Nature (Lond.). 319:780-787.

45. Hall, A., C. J. Marshall, N. K. Spurr, and R. A. Weiss. 1983. Identification of a transforming gene in two human sarcoma cell lines as a new member of the ras gene family located on chromosome 1. Nature (Lond.). 303:396-400.

46. Israel, M. A., C. J. Thiele, J. Whang-Peng, C. Kao-Shan, T. J. Triche, and J. Miser. 1985. Peripheral neuroepithelioma: genetic analysis of tumor derived cell lines. In Advances in Neuroblastoma Research. A. Evans, G. D'Angio, and R. C. Seeger, editors. Alan R. Liss, Inc., New York. 161-170.

47. Bolen, J. B., N. Rosen, and M. A. Israel. 1985. Increased pp60src tyrosyl kinase activity in human neuroblastoma is associated with amino-terminal tyrosine phosphorylation of the src gene product. Proc. Natl. Acad. Sci. USA. 8:7275-7279.

48. Rosen, N., J. B. Bolen, A. M. Schwartz, P. Cohen, V. DeSeau, and M. A. Israel. 1986. Analysis of pp60c-src protein kinase activity in human tumor cell lines and tissues. J. Biol. Chem. 261:13754-13759.

49. Westin, E. H., R. C. Gallo, S. K. Arya, A. Eva, L. M. Souza, M. A. Baluda, S. A. Aaronson, and R. Wong-Staal. 1982. Differential expression of the amv gene in human hematopoietic cells. Proc. Natl. Acad. Sci. USA. 79:2194-2198.

50. Lee, W., A. L. Murphree, and W. F. Benedict. 1984. Expression and amplification of the n-myc gene in primary retinoblastoma. $\mathrm{Na}$ ture (Lond.). 309:458-460.

51. Kohl, N. E., C. E. Gee., and F. W. Alt. 1984. Activated expression of the N-myc gene in human neuroblastomas and related tumors. Science (Wash. D.C.). 226:1335-1337.

52. Dalla-Favera, R., M. Bregni, J. Erikson, D. Patterson, R. Gallo, and C. M. Croce. 1982. Human c-myc onc gene is located on region of chromosome 8 that is translocated in Burkitt lymphoma cells. Proc. Natl. Acad. Sci. USA. 79:7824-7827.

53. de Klein, A., A. G. van Kessel, G. Grosveld, C. R. Bartram, A. Hagemeijer, D. Bootsma, N. K. Spurr, N. Heisterkamp, J. Groffen, and J. R. Stephenson. 1982. A cellular oncogene is translocated to the Philadelphia chromosome in chronic myelocytic leukemia. Nature (Lond.). 300:765-767.

54. Chen, J. H. 1985. The proto-oncogene c-ets in preferentially expressed lymphoid cells. Mol. Cell. Biol. 5:2993-3000.

55. Ghysdael, J., A. Gegonne, P. Pognonec, D. Dernis, D. LePrince, and D. Stehlin. 1986. Identification and preferential expression in thymic and bursal lymphocytes of c-ets oncogene-encoded $\mathbf{M r}$ 54,000 cytoplasmic protein. Proc. Natl. Acad. Sci. USA. 83:17141718.

56. Rothberg, P. G., J. M. Spandorfer, M. D. Erisman, R. N. Staroscik, H. F. Sears, R. F. Peterson, and S. M. Astrin. 1985. Evidence that c-myc expression defines two genetically distinct forms of colorectal adenocarcinoma. Br. J. Cancer. 52:629-632. 